The radial bars are of equal length-I employ the word "lengrth" for brevity, to derote the distance between the pivots, the links, of course, may be of any length or shape, - and the distance between the pivots or the traversing link is such that when the radial bars are parallel the line joining those pivots is perpendicular to the radial bars. The tracing-point is situate half-way between the pivots on the traversing piece. The curve described by the tracer is, if the apparatus does not deviate much from its mean position, approximately a straight line. The reason of this is that the circles described by the extremities of the radial bars have their concavities turned in opposite directions, and the tracer being half-way between, describes a curve which is concave neither one way nor the other, and is therefore a straight line. The curve is not, however, accurately straight, for if I allow the tracer to describe the whole path it is capable of describing, it will, when it gets some distance from its mean position, deviate considerably from the straight line, and will be found to describe a figure 8 , the portions at the crossing being nearly straight. We know that they are not quite straight, because it is impossible to have such a curve partly straight and partly curved.

For many purposes the straight line described by Watt's apparatus is sufficiently accurate, but if we require an exact one it will, of course, not do, and we must try again. Now it is capable of proof that it is impossible to solve the problem with three moving links; closer approximations to the truth than that given by Watt can be obtained, but still not actual truth.

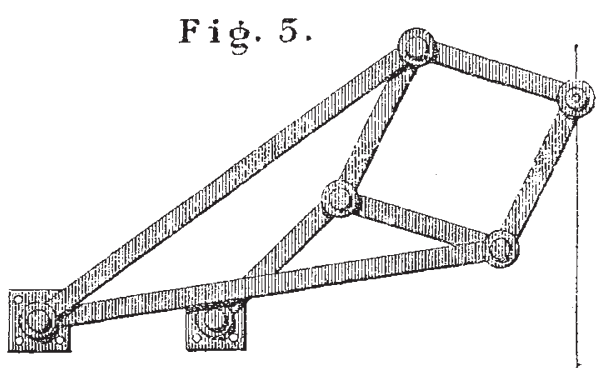

I have here some examples of these closer approxima tions. The first of these, shown in Fig. 3, is due to Richard Roberts of Manchester.

The radial bars are of equal length, the distance between the fixed pivots is twice that of the pivots on the traversing piece, and the tracer is situate on the traversing piece, at a distance from the pivots on it equal to the lengths of the radial bars. The tracer in consequence coincides with the straight line joining the fixed pivots at those pivots and half-way between them. It does not, however, coincide at any other point, but deviates very slightly between the fixed pivots. The path described by the tracer when it passes the pivots, altogether deviates from the straight line.

The other apparatus was invented by Prof. Tchebicheff of St. Petersburg. It is shown in Fig. 4. The radial bars are equal in length, being each in my little model five inches long. The distance between the fixed pivots must then be four inches, and the distance between the pivots or the traversing bar two inches. The tracer is taken half-way between these last. If now we draw a straight line-I had forgotten that we cannot do that yet, well, if we draw a straight line, popularly so calledthrough the tracer in its mean position as shown in the figure, parallel to that forming the fixed pivots, it will be found that the tracer will coincide with that line at the points where verticals through the fixed pivots cut it as well as at the mean position, but, as in the case of Roberts's parallel motion, it coincides nowhere else, though its deviation is very small as long as it remains between the verticals.
We have failed then with three links, and we must gs on to the next case, a five-link motion-for you will observe that we must have an odd number of links if we want an apparatus describing definite curves. Can we solve the problem with five? Well, we can, but this was not the first accurate parallel motion discovered, and we must give the first inventor his due (although he did not find the simplest way), and proceed in strict chronological order.

In 1864 , eighty years after Watt's discovery, the problem was first solved by $M$. Peaucellier, an officer of Engineers in the French army. His discovery was not at first estimated at its true value, fell almost into oblivion, and was rediscovered by a Russian student named Lipkin, who got a substantial reward from the Russian Government for his supposed originality. However, M. Peaucellier's merit has at last been recognised, and he has been awarded the great mech inical prize of the Institute of France, the "Prix Montyon."

M. Peaucellier's apparatus is shown in Fig. 5. It has, as you see, seven pieces or links. There are first of all two long links of equal length. These are both pivoted at the same fixed point; their other extremities are pivoted to opposite angles of a rhombus composed of four equal shorter links. The portion of the apparatus I have thus far described, considered apart from the fixed base, is a linkage termed a "Peaucellier cell." We then take an extra link, and pivot it to a fixed point whose distance from the first fixed point, that to which the cell is pivoted, is the same as the length of the txtra link; the other end of the extra link is then pivoted to one of the free angles of the rhombus; the other free angle of the rhombus has a pencil at its pivot. That pencil will accurately describe a straight line.

I must now indulge in a little simple geomctry. It is absolutely necessary that I should do so in order that you may understand the principle of our apparatus.

(To be continued.)

\section{FOSSIL FLORAS AND GLACIAL PERIODS}

A RECENT notice in NATURE (vol. xiv. p. 336) of certain $A$ inferences of Prof. Heer in connection with the Arctic fossil plants obtained by the Swedish Expeditions of 1870 and 1872 , suggests some thoughts on the relations of fossil plants to climate, which, though I have discussed them elsewhere, deserve to have attention again directed to them. In my Bakerian Lecture before the Royal Society in 1870 , and in my "Report on the Pre carboniferous Flora of Canada," published by the Canadian Survey in $187 \mathrm{I}$, I deduced from the generalisations of Prof. James Hall as to the growth of the American Continent from the north-east, in connection with the distribution of the fossil plants of the Upper Silurian, Erian, and Carboniferous systems, the conclusion that these assemblages of plants entered North America from the north-east, and propagated themselves southward and westward. Prof. Asa Gray had, as early as I 867 , stated similar conclusions with reference to the modern floras of America and Eastern Asia, and has more recently extended them to the Tertiary floras on the evidence of Heer and Lesquereux. ${ }^{1}$

The further conclusion that all the old floras appeared suddenly and abruptly in the temperate regions, and with a great number of species, I have illustrated in the Report above referred to, as far as regards the Palæozoic plants, and have referred to the evidence of it in the case of the Cretaceous and Tertiary floras in my address to the American Association in 1875 .

With regard to the succession of these floras, it is true that it has been the fashion with certain European palæontologists to regard our rich Devonian or Erian flora

- Address to the American Association, $x 872$. 
of America as of Carboniferous age, simply because it contains forms not found as yet in rocks so old in Europe. But this notion is at variance with stratigraphy and animal fossils, and quite as wide of the mark as the often-repeated dictum of some of the same authorities that the Cretaceous flora of Vancouver Island and the Eocene flora of the North-western plains are equivalents of the European Miocene. In point of fact, we have in America distinct floras of Erian and Carboniferous age with an intermediate sub-flora of Lower Carboniferous date, ${ }^{\mathrm{I}}$ and succeeding them the Triassic and Jurassic flora, that of the Cretaceous, that of the Eocene, and that of the Miocene; and there is good reason to believe that all of these invaded the Continent from the northward and lingered longest in the south. There may no doubt have been counter migrations from the south, but these scem to have left less trace in the geological record. The special Lower Carboniferous or "Culm" flora, and that of the Eocene in Europe, may be of this character.

If we compare these facts with those known from other sourccs as to the alternation of cold and warm climates in the northern hemisphere, it would seem that they harmonise most closely on the hypothesis advocated by Sir Charles Lyell, that these changes of climate have depended mainly on the distribution of land and water and of the ocean currents.

Assuming a condition in which much tropical land cxisted, along with islands in the Arctic and sub-Arctic regions, surrounded with deep water over which warm currents were distributed, a rich flora might extend as far northward as the supply of light would permit. Further, if such condition of equatorial protuberance were coincident with a less obliquity of the ecliptic, there might be icss difficulty with regard to a continuous supply of light than under present circumstances. Succeeding elevation of northern and temperate land and depression of that nearcr the equator, would destroy the more southern flora and cause that of the north to advance over the newlyelevated continental plateaus. This would more especially be the case if, as we may infer from the possible connection of equatorial subsidence with the retardation of the earth's rotation, the depression of the northern land was very slow and gradual, and that of the equatorial land more sudden and paroxysmal.

Invasions of plants from the north would thus result from continental elevation in the temperate regions, and these invasions would go on contemporaneously with the introduction of less equable and cooler climatal conditions. These might not, however, advance so far as to cause extreme glacial phenomena, except in those, perhaps rare, circumistances, when Arctic land was elevated while the greater part of the tropical and temperate areas remained under shallow seas with little heating and radiating surface and invaded by much northern ice. Further, when we take into consideration the growth of the continents in later geological times, it is evident that such periods of exceptional cold would be more likely to occur in these later times, and that they might be less intense in earlier geological periods, and might attain their maximum in the last glacial period. They would also be irregular as to the intervals between them, and might through long periods be absent altogether. We have proof of the efficacy of such causes in the contrast between the climates of Labrador and England at the present day, and also in that sameness of the climate of those regions in the Postpliocene period, of which I long ago pointed out the evidence in my "Acadian Geology." Such moderate views as to glacial periods may also serve to render more explicable the facts as to the absence of evidence of glacial action in Arctic Tertiary formations as observed by Nordenskjöld.

It will of course be understood that my conception of glacial periods is not that of continental ice-caps; but

\footnotetext{
T Tweedian of North of England, Culm of Germany.
}

rather such conditions as would cover great breadths of shallow sea in the northern hemisphere with a permanent and continuous ice-pack, accompanied of course with "bordage" and "anchor ice" and with glaciers descending to the sea from high lands; the whole resembling that now occupying large areas of the Arctic seas, and occurring in winter in the Gulf and River St. Lawrence. To such agencies I have been accustomed for the last twenty years to refer our Canadian boulder clay and glaciated rocks. Further, to this extent we have evidence, locally at least, of ice-action in temperate latitudes (in non-fossiliferous conglomerates with boulders) as far back as the Huronian age, while the evidence of alternate submergence and emergence of the northern land extends down to that of the Post-pliocene, whose greatness geolo gists are only beginning to realise.

It is a corollary from these views that there can have been no change within geological time in the position of the earth's axis of rotation. The distribution of sediment by the polar currents, and the lines of plication and upheaval of the crust, as well as the distribution of successive floras, prove that the poles have remained since the Laurentian period where they now are. I need here merely refer to the fact, well known to all American geologists, that the earthy matter of the thick Appalachian sediments lies parallel to the line of the modern Arctic currents, which seem in all geological time to have been potent agents in carrying the débris of the disintegrated Arctic rocks to the south, and filling up the voids caused by equatorial subsidence. Further, the great organic limestones, which represent the contemporaneous foodbearing warm currents from the equator, lie on the plareaus and in the bays of the old Eozoic and Palcozoic land.

We need not, however, in consistency with such views, refuse to attach any importance which they may seem to require to astronomical cycles affecting the eccentricity of the earth's orbit and the precession of the equinoxes, or to the possible diminution or inequality of solar energy, or to the secular cooling and contraction of the earth or the retardation of its rotation. But geologists and palæontologists, in speculating on past conditions of the earth, should endeavour in the first instance to gauge the value of the causes indicated by their own sciences; and where climate is in question no evidence can be more important than that of continental elevation and depression, in connection with the appearance and diffusion of those assemblages of land plants which furnish so sure testimony as to climatal influences.

I should perhaps apologise for throwing out these suggestions with so lit:le of illustration or proof. For much of this I may refer to my published memoirs ; ${ }^{I}$ and I have now before me a mass of additional evidence, collected in all the great regions from Newfoundland to British Columbia by several recent observers, which I have not at the moment time or opportunity to throw into a connected form. My present object is to invite the attention of the many young and active geologists now working at these subjects to lines of investigation from which they may be deterred by some of the theoretical views now current.

McGill College, Montreal

J. W. DAWSON

\section{A NEW STIMULANT-PITURY}

BARON VON MUELLER writes to the Australian Medical Fournal on the origin of the Pitury, a stimulant said to be of marvellous power, and known to be in use by the Aborigines of Central Australia. After years of efforts to get a specimen of the plant, he had obtained leaves, but neither flowers nor fruits. He can almost with certainty, after due microscopic examination,

? Especially the Report above referred to, and "Notes on the Postpliocene Geology of Canada," Canadian Naturalist, New Series, vol. vi. 